Article

\title{
A Political Space for Children? The Age Order and Children's Right to Participation
}

\author{
Jeanette Sundhall \\ Department of Cultural Sciences, Gothenburg University, 40530 Gothenburg, Sweden; E-Mail: jeanette.sundhall@gu.se
}

Submitted: 31 March 2017 | Accepted: 17 July 2017 | Published: 26 September 2017

\begin{abstract}
This article discusses how adulthood is naturalized and how adulthood norms set limits on the possibilities of including children in democratic processes and understanding them as political subjects. The article examines the kind of resistance children and youth can meet when participating in democratic processes, with examples of speech acts from the Gothenburg Youth Council. It also discusses the theoretic concept of childism (Wall, 2008, 2010) and how childism can be a way to escape the dominance of adulthood norms. The concept of childism means addressing children's experiences by transforming understandings and practices for all humans, not only for non-adults. How is it possible to create a political space for children and involve children in defining what should count as politically important?
\end{abstract}

\section{Keywords}

adulthood norms; age order; childism; participation; youth council

\section{Issue}

This article is part of the issue "Promoting Children's Participation in Research, Policy and Practice", edited by Jo Aldridge (Loughborough University, UK).

(C) 2017 by the author; licensee Cogitatio (Lisbon, Portugal). This article is licensed under a Creative Commons Attribution 4.0 International License (CC BY).

\section{Introduction}

In this article, I discuss how adulthood norms set limits on the possibilities of including children in democratic processes and understanding them as political subjects. Adulthood norms are norms that imply an adult position which is implicit, invisible and thus naturalized. The theoretical starting point of this article is thus that adulthood is naturalized and fundamental to an understanding of the age categorization of children, and also that age (like gender) is constructed relationally. One is always young, old, older, or younger relative to someone else, but also relative to a certain context.

Since it started in the 1980's, the research field of childhood studies has had the stated ambition of reducing the difference in power between children and adults. The research field launched concepts like: the child as an actor, the competent child, children's participation. These concepts are about recognizing children as full human beings and as equivalent to adults (Alanen 1988, 1992; Hockey \& James, 1993; James, Jenks, \&
Prout, 1998; James \& Prout, 1990; Qvortrup, 1994). This has been criticized by John Wall (2012) who argues that concepts like agency and competence assume and reproduce an adulthood norm where rights are not absolute but must be earned. In this article, I use Wall's concept of childism in order to critically examine a case and discuss current structures and norms, as childism offers a tool for deconstructing the naturalisation of adulthood.

In the field of childhood studies, the meanings and the effects of adulthood are not much discussed. Just as theoretical approaches in queer theory and critical whiteness studies focus on the superior position and show that it is important not to restrict examination to the subordinate position, I believe that this idea is equally important when it comes to power relations between children and adults.

\section{Age as a Power Order}

The idea of working for children's increased participation, which is formulated in Article 12 in the UN convention 
on the rights of the child, is based on knowledge that, due to their age, children and young people are underrepresented in political processes and are seldom heard in public. Age is a widespread and accepted reason to treat people differently. Age and different ways of regulating age are common ways to create social order (Näsman, 2004). That is why age can be regarded as a power order; a social order which carries hierarchies and discrimination, inclusions and exclusions. Ideas and norms regarding age are used in order to organize and discipline individuals, activities, and contexts. Age is regarded as a "neutral belonging" and these organizations thus gain an objective character as something biological and chronologic (Krekula, Närvänen, \& Näsman, 2005; Närvänen, 2009).

The life phase of adulthood is generally ascribed a higher status when compared to other life phases since the individuals here are considered nourishing: they are contributing to the survival of society. The individuals belonging to the life phases of childhood, youth, and old age are, on the contrary, regarded as consuming: they are not contributing to society but merely using its resources (Hockey \& James, 1993; Närvänen \& Näsman, 2007).

Age is made binary by the division into children and adults, although age categorizations contain concepts such as teenager, youth, and young adult, which soften this binary division and imply that the boundary between child and adult is a flexible one (Sjöberg, 2013). In practice, however, children and adults are often positioned in a binary way. The naturalization of adulthood also means that it constitutes the unmarked age (Krekula \& Johansson, 2017). The unmarked age is that which other age categorizations are related to and which itself constitutes the norm. In the case of adulthood, this is an invisible norm: a naturalization. Adulthood is so fundamental to being seen as a full human that we view it as natural that children are considered not yet fully human. Thus, adulthood becomes naturalized and at the same time age becomes a legitimate power order when it comes to the age categorization of children, since children's subordination is regarded as something natural and often even desirable; children are viewed as "under development" and in need of adult protection and care.

My position in analysing and discussing adulthood norms is that it is not enough to analyse only the subordinate position, that of the child. In order to understand how dominance relations are constructed, reproduced, and challenged, it is also necessary to examine the superior position.

Age is constructed relationally in that the child categorization comprises characteristics such as immaturity, volatility, and spontaneity (in the sense of being nonreflective), while the adult categorization is constructed as the opposite: adult individuals become mature, stable, and reflective. The child categorization thus contributes to the association of adulthood with positive qualities (Alanen, 1992). When children are understood as under development and in need of protection, this gives legitimacy to the primacy of adults which can be compared to how women, in a binary understanding of gender, are constructed as weak and emotionally unstable and how this gives legitimacy to male superiority. The age order is about how adults use children to define themselves in an ideological process of dominance and self-definition that can be compared with processes where men have defined women and colonizers have defined the persons they colonized as "the Other" (Sundhall, 2012; Thorne, 1987).

The emphasizing of children's agency in the field of childhood studies has resulted in children being discussed in terms of citizenship, a concept that has traditionally completely excluded children (Archard, 1993; Freeman, 2011; Nakata, 2015; Oswell, 2013). In societies that regard themselves as democratic, there is still a large part of the population who are not permitted or assumed to be a part of the political life and to be involved in formulating what is politically important. This applies to the age categorization of children, who are excluded due to their chronological age. Their exclusion is thus due to their difference compared to the norm of the citizen, a synonym for the adult subject.

The basis for this article is an analysis of speech acts concerning the Youth Council of Gothenburg, Sweden, which I use to discuss how adult norms are naturalized and consolidated but also how they are made visible and challenged. This analysis of speech acts involves poststructuralist ideas of how language is performative and my interest in different kinds of texts focuses on what the text is doing and not what it means. I will use the concept of childism (Wall, 2008, 2010) and discuss how it can be a way to escape the dominance of adult norms. The concept of childism means addressing children's experiences by transforming understandings and practices for all humans, not only for non-adults. Childism can then be an approach which challenges and changes structures and possibilities (Wall, 2010).

\section{The Significance of Speech Acts for the Dominance of Adulthood}

The naturalization of adulthood implies that it can be hard to spot, though the effects of the naturalization may be easier to uncover. One effect emerges through an embodiment and repetition of norms which lead others to believe in their naturalizing effects (Butler, 1993). Explicit references to adulthood and its prerequisite childity (Sjöberg, 2013) are often used for disciplinary purposes: "Grow up! Don't be such a baby! You're acting like a three-year-old!" Often, these references are made without anyone reflecting on how these speech acts work in a discriminatory and subordinating way, not towards those the words are directed against but to those who fit into the age categorization of children. The effect of the speech acts is thus to confirm the normality of adulthood. Some constructions function in such a naturalizing 
way that one no longer understands that they are constructions or that the function is subordinating.

\section{The Need to Redefine Key Concepts}

One aim of this article is to consider how to seriously include children in democratic processes. Two theorists who have discussed this issue by starting from the concept that adult norms are in control are Moosa-Mitha (2005) and Wall $(2008,2010,2012)$. Both propose that the very definitions of concepts like democracy and human rights are problematic, not least in ownership of the right to define them. The conclusion is to redefine what democracy and human rights actually mean-only then can children be included.

Moosa-Mitha has discussed how adult norms exclude children by defining democracy and human rights as something that children do not yet deserve and that an implicit adulthood is used as the standard of a real citizen (Moosa-Mitha, 2005). If we instead reflect on the basis of alternative models of citizenship-models that put difference at their centre-we can see possibilities of defining children's citizenship in ways that take children's rights and status as citizens seriously, due to their identities as children rather than despite them (MoosaMitha, 2005).

Moosa-Mitha takes as a starting-point the more fluid and pluralistic way in which feminist theorists discuss difference by thinking about citizenship as situated in a politics of solidarity; a transversal politics where citizens with multiple subject positions get together and enact resistance against oppression (Moosa-Mitha, 2005). MoosaMitha also uses the concept differently-equal, as proposed by Yuval-Davies (1999). By emphasizing difference before equality, Yuval-Davies suggests that it is through difference that equality is defined and that difference can become the very foundation of citizenship, rather than a place of exclusion (Moosa-Mitha 2005; YuvalDavies, 1999).

Moosa-Mitha discusses how difference is related to citizens' experiences of belonging and participation, and how citizenship is thus characterized by a recognition of citizens' differences regarding specific historical circumstances, vulnerabilities, and interests. The concept of participation can be widened to encompass an understanding of participation as an expression of agency, no matter how differently that agency is expressed. Presence is central in this understanding. It is not enough to have a voice; in order to have a presence in society, one's voice also has to be heard. Not to acknowledge the presence of a citizen is itself a form of oppression (MoosaMitha, 2005). Being treated as an equal member of society means having one's personal concerns viewed as questions of general importance. Since participation in the public sphere is so important for this, an exclusion from participation implies that one is excluded from being able to perform one's citizenship.
An alternative view of children's rights of equality would focus on normative assumptions and beliefs of social institutions that are gendered, racialized and adultist, and which exclude children from belonging as equals both within and outside the family. (MoosaMitha, 2005)

For children, belonging as equals in society is a prerequisite for being able to participate in democratic processes and being able to be understood as political subjects.

\section{Childism}

John Wall follows the same route as Mehmoona MoosaMitha in discussing the concept of childism. Childism is a concept that was coined by two different theorists and it has two different meanings. I will here assume the definition of John Wall, which is completely opposed to YoungBruehl's definition as discrimination against children (cf., sexism and ageism). Wall's definition is about redefining central norms so that they can include children's experiences, which is exactly what Moosa-Mitha discusses. The whole theory of human rights is constructed around adulthood. In all of the justifications of why humans should have human rights, children are placed in a position of lacking the right to have rights (Wall, 2008). Rights belong to rational subjects and throughout western history rationality has been discussed as a qualification possessed by the adult subject, but not by the child. In this understanding, children can only be nurtured, disciplined, or educated into rational individuals (Wall, 2008).

The inclusion of children in democratic processes requires an extended concept of the political subject and the political terrain. According to Wall, this new concept, which is analogous to feminism, queer theory, and environmentalism, is childism. In discussing concepts such as agency and representation in relation to political inclusion, Wall points out that the idea of politics as an expression of agency is not a new one, but derives from the Enlightenment. Until now, it has been possible to conceive of children as second-class citizens because agency is connected to an autonomous and independent adulthood. Agency is, in itself, a political norm based on a historical, adult-centred preconception. This understanding of agency attempts to fit children into political constructions which take adulthood as their starting point, rather than challenging the constructions themselves (Wall, 2012).

The result of this is the proposal of a model where children's political citizenship is based on interdependence, which is about an individual's simultaneous active independence and passive dependence. The advantage of basing citizenship on interdependence rather than agency is that children and adults then become more equal. However, according to Wall, children's voices will still be marginalized in such a dialogue because of the historical oppression against them. What is needed is a 
a political space where children are entitled to express their own views and claim their difference toward others (Wall, 2012).

Regarding the difference model advocated by MoosaMitha, Wall argues that this model has the advantage of giving children the chance to claim historical marginalization. The difference model can be used to deconstruct the normative assumptions which view children as not being complete political subjects. The difference model also makes it clear that children are not a homogeneous group but, like all other age categorizations, are living under various circumstances and therefore might participate in politics in various ways. However, Wall argues that the model is nevertheless problematic because one of the most significant ways in which children are "different" is that they generally have less experience in fighting for political power (Wall, 2012). Age has an actual effect on one's ability to execute political action and children have usually participated in political life for fewer years than adults. Age implies a genuine difference when it comes to the ability to fight on behalf of one's difference (Wall, 2012). The solution to this problem, Wall argues, is to rethink the foundations of political representation in a way that is simultaneously both interdependent and difference-oriented.

This can be done, I now argue, by learning about the larger meaning of democracy from children's particular experiences. What is learned is that political representation should ultimately mean empowering lived differences to make a difference to interdependent political structures. The negative aim of deconstructing power meets the positive aim of creating community in the truly democratic aim of a differenceresponsive political whole. (Wall, 2012)

Wall emphasizes that children can be understood as politically responsible. Being politically represented does not only mean expressing one's own interests, but rather, along with others, creating a more diversely constructed political whole (Wall, 2012).

\section{The Youth Council of Gothenburg: An Attempt to Include Children in Democratic Processes}

Some attempts have been made to include children in the political context and cater for children's right to participation. These include, for example, the child and youth parliaments that are available in at least 30 countries, either on a national or a municipal level. These parliaments are often initiated by adults and researchers in the field have discussed how adults in many ways simultaneously extend and shrink the political and civil participation of children and young people (Kawecka Nenga \& Taft, 2013). Youth councils and children's parliaments have also been criticized by researchers for being elitist, adult-led, and empty symbols of participation (Gordon \& Taft, 2011). Researchers have also discussed examples of children's parliaments where children and youth exercise direct, political power and achieve significant differences in their societies (Wall, 2012). Some relatively new movements are working for child-friendly cities and build upon a growing attention to "the rights to the city". This refers not only to individual access to resources, but also to exercising collective power in order to promote urban development. Child-friendly cities not only aim to provide safe and accessible spaces but also opportunities for children's and young people's participation in local decisionmaking (Flanders Cushing \& van Vliet, 2016). The city of Gothenburg has the explicit aim of being "a children's and youth city" and it is declared that "the young perspective is especially important to the decision-makers of the city" and also that a goal of the city is that "young citizens of Gothenburg shall be given increased opportunities to influence" (City of Gothenburg, n.d.).

Gothenburg has had a Youth Council since 2004. The website of this Council states that:

The Youth Council consists of 101 young people from all districts of Gothenburg. In the Youth Council, young people between 12-17 years of age meet and discuss various questions concerning young people in Gothenburg. It is the young people themselves who decide which questions are to be discussed. Via the Youth Council, you who are young have the opportunity to influence municipal committees, boards, companies, and administrations. (Youth Council, n.d.)

My overall intention in researching the Youth Council was to examine how children and adults cooperate in projects like this, projects aiming at children's right to participate in society. It was when I attended a conference during which the Youth Council presented their work that I first began to pay attention to the Youth Council. At the conference, an adult in the audience suggested a topic she considered adequate for the Youth Council to engage in: boys taking a lot of space in the classroom at the expense of girls. The Youth Council chairperson on the stage agreed with the problem at first, but then reacted with slight annoyance and responded that that should be the responsibility of the teachers and that more importantly it is the Youth Council members themselves, not adults, that formulate the issues they want to work with. On this occasion, I came to reflect on the possibility of adults taking over the privilege to formulate issues that they think is appropriate for the Youth Council to engage in and the consequences of such an approach.

During the two years that I have followed the work of the Youth Council, it has become clear to me that much of the Council's work is aimed at ending the segregation between different parts of Gothenburg. Public transport, for example, has been a matter of great concern. Over the past ten years, the Youth Council has been working on the issue of expanded and free public transport. Their accomplishments have included the securing of free public transport for all schoolchildren until $10 \mathrm{pm}$ on week- 
days (instead of $7 \mathrm{pm}$ ), as well as a summer holiday card which gives free travel for all schoolchildren between the ages of 12 and 17 for three months during the summer. It is my understanding that the Youth Council consider public transport a question of justice on two levels: firstly, children and young people should not have to be dependent on their parents or guardians; and secondly, children and young people should be able to travel anywhere in the city and not be limited to a particular area.

In a meeting concerning public transport, the members of the Youth Council argue in favour of free public transport for children and youth. The adults invited to the meeting, a politician and a delegate from a transport company, do not agree with the Youth Council's description of children and youth as a particularly vulnerable group in society when it comes to economic issues. One of the adults says: "Free public transport for children and youth would promote justice and integration more for young people than for other groups. Justice is a broad concept." A Youth Council member argues: "As an adult, you create your own life but as a child you are born into an economic situation. You have less opportunity to influence your economic situation." In doing this, the Youth Council member is making the general power differences between children and adults explicit and the age order, which is often invisible and unproblematized, is made visible. After some exchanges of views, the adults at last agree with the Youth Council members' arguments about the specific experiences of being children and being dependent on adults. It is an example of childism when the Youth Council members, from their positions as nonadults, claim that their position differs from the privileged position of adults, in terms of dependence and the possibility of influencing one's life conditions (Field notes 2016-05-09).

I have attended several meetings and workshops initiated by the Youth Council to which they had invited adult politicians and officials. Sometimes I have recognized that the adults are doubtful about or question the ideas and proposals presented by the Youth Council. However, I have never seen such resistance from the adults as regarding the water slide discussed below. For this reason, I found it a particularly interesting case to examine.

During the summer of 2015, the Youth Council wanted to organise a 140-metre-long water slide at the annual Gothenburg Culture Festival. The aim of the water slide was to "create a meeting space for young people from all districts. The Youth Council believes that meetings between young people from various backgrounds and conditions contribute to greater integration" (Official statement on 2015-05-19 ref: 1130/15). The Youth Council would also inform about their work in connection to the water slide in order to reach more children and youth.

The Youth Council have an annual funding of 300000 Swedish kronor (equivalent to about 31663 euros) and the cost of organising the water slide was calculated at 165000 Swedish kronor. Since this would exceed 10000
Swedish kronor, the Youth Council, according to a regulation, had to ask permission from the City Council. The response from the City Council consisted of two texts, one from each political bloc. I will now discuss how adult norms are both made visible (and thus challenged) and made invisible (and thus reproduced) in the texts. One of the political blocs stated:

The Youth Council is an important part of the City's work to increase participation and impact among young people. Consequently, it is important to reach out widely among the young people of the City so that as many as possible get the opportunity to be heard. To increase the awareness of the Youth Council and its work is thus an important part of the work....A considerable sum of the Youth Council's budget will be used to rent a so-called water slide which will be the centre of attention for the activities of the Youth Council and act as a draw. This is a priority that may seem strange to many adults. However, the idea of the youth council was not that all of its decisions should be like the ones that adults would have made, but that new perspectives should come through....Last but not least we would like to offer the idea of not having an upper age limit, so that we who are older also get an opportunity to try the water slide (Opinion S,MP,V Gothenburg City Council 2015-06-10. Errand 2.2.5).

The other opinion was formulated thus:

It is unusual, if it has even ever happened, that the City Council have felt it necessary to contradict a proposal from The Youth Council. However, the current proposal has a scope and design that cannot pass unnoticed. Firstly, the proposal provokes thoughts about the size of the budget. The budget of 300000 corresponds to the full annual city tax payment of five wage earners. There are a lot of working hours behind this money that the Youth Council can dispose of freely. Now the Youth Council wishes to use half of that money on a water slide (Opinion M, FP,KD. Gothenburg City Council 2015-06-10. Errand 2.2.5).

The opinions from the City Council are examples of speech acts where the adult norm is reproduced but also challenged. In the first text, a problematizing of the adult norm is formulated: "This is a priority that may seem strange to many adults", with the effect that the adult norm is no longer naturalized but rather made visible. It is also emphasized here that the idea behind the Youth Council is to enable new perspectives and promote decisions that adults perhaps would not make, which is a formulation that points to a childistic perspective: that the right to define what is politically important does not solely belong to adults but to children as well. The last sentence of the opinion is a playful way of breaking up the power relation through an appeal not to exclude adult water slide riders. 
The second text contains different formulations which are not as playful. That the "five wage earners" are adults does not need to be written and as a result the power relation the opinion is based on is made invisible. These "working hours" are contrasted with the statement that the Youth Council "dispose...freely" of 300000 Swedish kronor every year, and the opinion ends with a call for a review of how the Youth Council's money has been used in recent years:

We would like a review of how the Youth Council's budget has been used in recent years. The support given to the Youth Council given by the City needs to combine the procurement of young people's ideas with expertise in how the aims of the initiatives are best met.

The emphasis that the Youth Council "freely" has responsibility for 300000 Swedish kronor and the contrasting of this sum against the working hours behind it have a disciplinary undertone. The fact that children are not given the possibility of performing professional work under the same conditions as adults, both due to compulsory school attendance and various age limitations in working life, and thus are not given the same opportunities as adults to contribute to the economy of the society is made invisible. Adult norms remain naturalized through the speech act in the opinion. Moreover, the request for "a review of how the Youth Councils budget has been used in recent years" could be interpreted as a threat. Is the Youth Council really capable of dealing with that much money? What have they actually accomplished? Formulations like "the support...given by the City" and "expertise" imply that adult power is active; that adults have the power to define what is right and wrong in relation to the assignment of the Youth Council. "Expertise" is formulated as something adults can possess and offer children rather than something that the members of the Youth Council can have themselves.

The adult politicians do not seem to consider the possibility that the members of the Youth Council have themselves already discussed the high cost of the water slide. However, such a discussion did take place and some of the members were doubtful whether it was "worth such a large part of our budget". One member said:

I am doubtful of the idea. It's good to have a deeper thought behind an activity so we fulfil our aims....If you consider the adults in society who've been working and paying taxes...we're responsible for every krona we're using from the municipality. It is more important than the water slide. It can give quite the wrong signals. I think we should spend the money on something useful. (Field notes 2015-04-20)

This member's argumentation against the water slide aroused protests among the other members, but one partly agreed:
I am ambivalent. It's a lot of money, but it's a good cause. Of course, some people will think that it's a waste and that it'd be better to invest in something serious (Field notes 2015-04-20).

Thus, the adult norms were not upheld solely by individuals who are categorized as adults-and this is how norms work. Norms are not only reproduced or challenged by the groups which benefit from the norm; we all contribute to them (Butler, 1993).

\section{Childism: Reclaiming the Childish and Making Fundamental Change}

The water slide finally got clearance from the City Council and following a cold spell the weather changed in time for the August days during which the event was held. The local paper Göteborgs-Posten reported that "Thousands got to try the water slide. There were at least 6500 rides on the 140-metre-long water ride this week-end" (Martinsson, 2015).

The chairperson of the Youth Council during 2015, Morgan Landström, was quoted in the print version of Göteborgs-Posten as saying:

We wanted to contribute to the Culture Festival and a water slide feels at the same time summery and childish. To us, it is important to create a place of community and openness for the youth of Gothenburg. (Dalghi, 2015)

Here, Morgan is reclaiming the word childish by using it in a clearly positive way. Refusing to accept the idea that childishness should represent anything negative is a way to challenge current adult norms.

One reason for the City Council's approval of the water slide was the idea that the Youth Council should evaluate whether the event really did become a meeting place for young people from all over Gothenburg. The Youth Council thus performed a survey asking what districts the water slide riders came from. The results showed that children and young people came from all over Gothenburg to ride the water slide, and that the event got very good reviews: "The result is, to say the least, a positive one; $99 \%$ of the respondents had a positive opinion and $41 \%$ felt that a water slide was the best idea ever. No one thought that it was rubbish or bad" (Youth Council, 2015).

How, then, can we understand the possibilities of including children in democratic processes and understanding them as political subjects? How can a childistic perspective challenge the adult norms which set limits on this? Childism implies thinking in a new way and enabling a broader understanding of democracy through the specific experiences of children. The positions which decide what is to be considered politically important are held by adults. Child and youth parliaments can have the effect of leading children to embrace adult values but 
they can also enable children to challenge the political worlds surrounding them in surprising and unforeseen ways (Wall, 2012). The discussion about the water slide exemplifies the thoughts of Mehmoona Moosa-Mithas and John Walls about how children's own lived realities and subjective experiences can dissolve adulthood's construction of power (Moosa-Mitha, 2005; Wall, 2012). A truly child-inclusive society is not a society where children are simply made into the equals of adults, but rather a society that allows itself to change fundamentally in answer to what makes children different (Wall, 2010). Human rights have always pointed to something beyond that which has been thought hitherto. The perspective of children can extend what it means to be human beyond "the white noise of adult-centrism" (Wall, 2010).

\section{Conclusions}

In this article, I have discussed the kind of resistance children and young people can meet when they are participating in democratic processes. The example of the water slide and the reactions to the proposal show the difficulties that children and young people are faced with during such participation and how they are questioned by adult norms. Every political proposal has to be open to criticism and this includes proposals from the Youth Council. However, it is how this is done that is interesting if one wants to try to understand what hinders children's participation and presence in society. The purpose of the Youth Council's water slide was to create a meeting place for children and young people in Gothenburg and the Council succeeded in creating this despite the resistance that they encountered. Childism is about being able to redefine the political landscape. The example of the Gothenburg Youth Council is not about changing the legislation or rephrasing policies but about the right to belong under the same conditions as adults and to be involved in defining what should count as politically important.

\section{Acknowledgments}

I gratefully acknowledge the members of the Youth Council of Gothenburg, and the council's coordinator Paula Aijmer, who kindly let me take part in their work. It has been really joyful and interesting for me to listen to the Youth Council's discussions and take part in their experiences.

\section{Conflicts of Interests}

The author declares no conflict of interests.

\section{References}

Alanen, L. (1988). Rethinking childhood. Acta Sociologica, 31.

Alanen, L. (1992). Modern childhood? Exploring the 'child question' in sociology. Jyväskylä: Jyväskylä Institute for Educational Research.
Archard, D. (1993). Children. Rights and childhood. London: Routledge.

Butler, J. (1993). Bodies that matter. On the discursive limits of "sex". New York: Routledge.

City of Gothenburg. (n.d.). Retrieved from http:// www.goteborg2021.com/jubileumsprojekt/av-ochmed-unga

Dalghi, B. (2015, August 15). Blöt fest vid Näckrosdammen. Göteborgs-Posten.

Flanders Cushing, D., \& van Vliet, W. (2016). Children's right to the city: The emergence of youth council in the United States. Children's Geographies. doi:10.1080/14733285.2016.1244602

Freeman, M. (2011). Children's rights as human rights. Reading the UNCRC. In J. Qvortrup, W. Corsaro, \& M.S. Honig (Eds.), The Palgrave handbook of childhood studies. London: Palgrave Macmillan.

Gordon, H. R., \& Taft, J. K. (2011). Rethinking youth political socialization: Teenage activists talk back. Youth \& Society, 43(4), 1499-1527.

Hockey, J., \& James, A. (1993). Growing up and growing old. Ageing and dependency in the life course. London: Sage.

James, A., \& Prout, A. (Eds.). (1990). Constructing and reconstructing childhood: Contemporary issues in the sociological study of childhood. London: Fallmer Press.

James, A., Jenks, C., \& Prout, A. (1998). Theorizing childhood. Cambridge: Polity Press.

Kawecka Nenga, S., \& Taft, J. K. (2013). Youth engagement: The civic-political lives of children and youth (Sociological Studies of Children and Youth, Volume 16). Bingley, UK: Emerald Books.

Krekula, C., \& Johansson, B. (2017). En introduktion till kritiska åldersstudier. In C. Krekula \& B Johansson (Eds.), Kritiska åldersstudier. Lund: Studentlitteratur AB.

Krekula, C., \& Närvänen, A.-L., \& Näsman, E. (2005). Ålder $\mathrm{i}$ intersektionell analys. Kvinnovetenskaplig Tidskrift, 2005(2-3).

Martinsson, A. (2015, August 17). Tusentals fick prova jätterutschkanan. Göteborgs-Posten. Retrieved from: http://www.gp.se/nyheter/goteborg/1.2804053-tu sentals-fick-prova-jatterutschkanan

Moosa-Mitha, M. (2005). A difference-centered alternative to theorization of children's citizenship rights. Citizenship Studies, 9(4), 369-388.

Nakata, S. (2015). Childhood citizenship, governance and policy. The politics of becoming adult. London: Routledge.

Närvänen, A.-L. (2009). Ålder, livslopp, åldersordning. In H. Jönsson (Ed.), Ålder, åldersordning, ålderism. Linköping: Linköpings universitet.

Närvänen, A-L., \& Näsman, E. (2007). Age order and children's agency. In H. Wintersberger, L. Alanen, T. Olk, \& J. Qvortrup (Eds.), Childhood, generational order and the welfare state: Exploring children's social and economic welfare. Odense: University Press of Southern Denmark. 
Näsman, E. (2004). Barndom, barn och barns rätt. In L. Olsen (Ed.), Barns makt. Uppsala: lustus Förlag.

Official Statement. Gothenburg City Council 2015-05-19. Ref 1130/15.

Opinion S,MP,V Gothenburg City Council 2015-06-10. Errand 2.2.5.

Opinion M, FP,KD. Gothenburg City Council 2015-06-10. Errand 2.2.5.

Oswell, D. (2013). The agency of children. From family to global human rights. New York: Cambridge University Press.

Qvortrup, J. (1994). Childhood matters: An introduction. In J. Qvortrup, M. Bardy, G. Sgritta, H. Wintersberger (Eds.), Childhood matters. Social theory, practice and politics. Aldershot: Avebury.

Sjöberg, J. (2013). I marknaden öga. Barn och visuell konsumtion (Linköping Studies in Art and Science No 581). Linköping: Linköpings universitet, Institutionen för Tema.

Sundhall, J. (2012). Kan barn tala? En genusvetenskaplig undersökning av ålder i familjerättsliga utredningstexter. Göteborg: Göteborgs universitet, institutionen för kulturvetenskaper.

Thorne, B. (1987). Re-visioning women and social change: Where are the Children? Gender \& Society, 1(1), 85-109.

Wall, J. (2008). Human rights in light of childhood. International Journal of Children's Rights, 16, 523-543.

Wall, J. (2010). Ethics in light of childhood. Washington, DC: Georgetown University Press.

Wall, J. (2012). Can democracy represent children? Toward a politics of difference. Childhood, 19(1), 86-100.

Youth Council. (n.d.). Retrieved from ungdomsfull maktige.se/homepage/home-v5

Youth Council. (2015). Survey waterslide.

Yuval-Davies, N. (1999). Ethnicity, gender relations and multiculturalism. In R. D. Torres, L. F. Miron, \& I. J. Xavier (Eds.), Race, identity and citizenship: A reader. Oxford: Blackwell.

\section{About the Author}

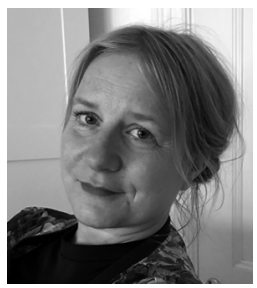

Jeanette Sundhall has a PhD in Gender Studies and works as a Senior Lecturer at the Department of Cultural Sciences, University of Gothenburg. Her research interests concern age categorizations, children's rights, and power orders and she is particularly interested in how ideas about adulthood are formulated and performed. 